\title{
NEW HILBERT DYNAMIC INEQUALITIES ON TIME SCALES
}

\author{
S. H. Saker, A. M. Ahmed, H. M. Rezk, D. O'Regan and R. P. Agarwal
}

Abstract. In this paper, we prove some new dynamic inequalities of Hilbert type on time scales. From these inequalities, as special cases, we will formulate some special integral and discrete inequalities. The main results are proved using some algebraic inequalities, Hölder's inequality, Jensen's inequality and a chain rule on time scales.

Mathematics subject classification (2010): 26D15, 34A40, 39A12, 34N05.

Keywords and phrases: Hilbert's inequality, Hölder's inequality, Jensen's inequality, time scales.

\section{REFERENCES}

[1] R. Agarwal, D. O'Regan and S. H. Saker, Dynamic Inequalities on Time Scales, Springer, Switzerland, 2014.

[2] M. Bohner And A. Peterson, Dynamic Equations on Time Scales: An introduction with applications, Birkhäuser, Boston, 2001.

[3] M. Bohner And A. Peterson (eds.), Advances in Dynamic Equations on Time Scales, Birkhäuser Boston, 2003.

[4] M. Bohner, A Nosheen, J. PeČarić And A. Younis, Some dynamic Hardy-type inequalities with general kernels, Math. Ineq. Appl. 8 (2014), 185-199.

[5] M. Bohner And G. Sh. Guseinov, Multiple integration on time scales, Dynamic Sys. Appl. 14 (2005), 579-606.

[6] L. DeBnath And B. YAng, Recent developments of Hilbert-type discrete and integral inequalities with applications, International J. of Math. and Mathematical Sci. (2012), Article ID 871845, 29 pages. doi:10.1155/2012/871845.

[7] T. Donchev, A. Nosheen And J. PeČARIĆ, Hardy-type inequalities on time scale via convexity in several variables, ISRN Math. Anal. 2013 (2013), Article ID903196, 9 pp.

[8] G. H. HARDY, Note on a theorem of Hilbert concerning series of positive term, Proc. London Math. Soc. 23 (1925), 45-46.

[9] G. H. Hardy, J. E. Littlewood and G. Pólya, Inequalities, $2^{\text {nd }}$ Ed., Cambridge Univ. Press, 1934.

[10] G. H. Hardy, J. E. Littlewood And G. Polya, The maximum of a certain bilinear form, Proc. London Math. Soc. 25 (1926), 265-282.

[11] G. H. HaRdy, Remarks in addition to dr. Widder's note on inequalities, J. London Math. Soc. 3 (1929), 199-202.

[12] G. H. HARDY, The constants of certain inequalities, J. of London Math. Soc. 8 (1933), 114-119.

[13] D. HILBERT, Grundzüge einer allgemeinen theorie der linearen intergralei chungen, Göttingen Nachr. (1906), 157-227.

[14] B. G. PaChPATte, On some new inequalities similar to Hilbert's inequality, J. Math. Anal. Appl. 226 (1998), 166-179.

[15] U. M. ÖZKAn AND H. YILDIRIM, Time scale Hardy-Knopp type integral inequalities, Commun. Math. Anal. 6 (2009), 36-41.

[16] S. H. Saker, R. R. Mahmoud and A. Peterson, Weighted Hardy-type inequalities on time scales with applications, Mediterr. J. Math. 13 (2016), 585-606.

[17] I. SCHUR, Bernerkungen sur theorie der beschrankten Bilinearformen mit unendlich vielen veranderlichen, Journal of Mathematics 140 (1911), 1-28. 
[18] A. Tuna And S. Kutukcu, Some integral inequalities on time scales, Appl. Math. Mech Eng. 29 (2008), 23-29.

[19] H. WEYL, Singulare integral gleichungen mit besonderer berucksichtigung des fourierschen integral theorems, [Inaugeral-Dissertation], W. F. Kaestner, Gottingen, Germany, 1908. 